\title{
Phloem Unloading of Potato virus X Movement Proteins Is Regulated by Virus and Host Factors
}

\author{
Tefera Mekuria,, ${ }^{1}$ Devinka Bamunusinghe, ${ }^{1}$ Mark Payton, ${ }^{1,2}$ and Jeanmarie Verchot-Lubicz ${ }^{1}$ \\ ${ }^{1}$ Department of Entomology and Plant Pathology and ${ }^{2}$ Department of Statistics, Oklahoma State University, \\ Stillwater 74078, U.S.A.
}

Submitted 30 January 2008. Accepted 4 April 2008.

To determine the requirements for viral proteins exiting the phloem, transgenic plants expressing green fluorescent protein (GFP) fused to the Potato virus $X$ (PVX) triple gene block (TGB)p1 and coat protein (CP) genes were prepared. The fused genes were transgenically expressed from the companion cell (CC)-specific Commelina yellow mottle virus (CoYMV) promoter. Transgenic plants were selected for evidence of GFP fluorescence in $\mathrm{CC}$ and sieve elements (SE) and proteins were determined to be phloem mobile based on their ability to translocate across a graft union into nontransgenic scions. Petioles and leaves were analyzed to determine the requirements for phloem unloading of the fluorescence proteins. In petioles, fluorescence spread throughout the photosynthetic vascular cells (chlorenchyma) but did not move into the cortex, indicating a specific barrier to proteins exiting the vasculature. In leaves, fluorescence was mainly restricted to the veins. However, in virusinfected plants or leaves treated with a cocktail of proteasome inhibitors, fluorescence spread into leaf mesophyll cells. These data indicate that PVX contributes factors which enable specific unloading of cognate viral proteins and that proteolysis may play a role in limiting proteins in the phloem and surrounding chlorenchyma.

Additional keywords: phloem transport, proteasome degradation, virus movement.

The phloem provides a path for long-distance translocation of various macromolecules, including photoassimilates, proteins, nucleic acids (including small interfering [si]RNAs), plant viruses, and viroids (Carrington et al. 1996; Carrington and Whitham 1998; Lucas and Wolf 1999; Nelson and Van Bel 1998). The companion cell (CC)-sieve element (SE) complex performs a central role in trafficking macromolecules throughout the plant. Branched plasmodesmata connecting CC and SE are termed pore-plasmodesmata units (PPU) and function for symplastic exchange of macromolecules between CC and SE (Oparka and Turgeon 1999; Van Bel et al. 2002). Sugars and other macromolecules which follow a symplastic route of exchange move via PPU between CC and SE (Oparka and Turgeon 1999).

Phloem unloading of proteins and nucleic acids is selective. The phloem-mobile Cucurbita PP1 and PP2 proteins are examples of proteins that are restricted from exiting the phloem even when other proteins are able to pass into nonvascular tissues. Although PP1 and PP2 have the ability to move across

Corresponding author: Jeanmarie Verchot-Lubicz; Telephone: +1.405.744 7896; Fax: +1.405.744.6039; E-mail: Verchot.lubicz@ okstate.edu plasmodesmata when manually delivered to mesophyll cells, they are unable to move across plasmodesmata connecting CC to parenchyma cells (Balachandran et al. 1997; Golecki et al. 1999). Viral movement proteins provide another example of positive effectors that enable viruses to selectively exit the phloem into nonvascular tissues. The Tobacco mosaic virus (TMV) and Red clover necrotic mosaic virus (RCNMV) movement proteins have been well described for their abilities to aid vascular transport and unloading of a broad range of plant viruses (Arce-Johnson et al. 1997; Deom et al. 1994; Giesman-Cookmeyer et al. 1995). Their abilities to function as positive effectors of virus transport were particularly highlighted by studies showing that the insect infecting Flock house virus (FHV) can spread systemically in transgenic plants expressing these plant viral movement proteins (Dasgupta et al. 2001).

There are numerous examples of RNA viruses, viroids, and cellular RNAs requiring protein chaperones for phloem translocation and unloading (Lough and Lucas 2006; Oparka and Turgeon 1999). The Potato viruses $X$ (PVX) triple gene block (TGB)p1 and coat protein (CP) were proposed to conduct viral RNA long distance through the phloem (Roberts et al. 1997). The cucumber and melon phloem P-proteins chaperone plant and viroid RNAs through sieve tubes (Gomez and Pallas 2004; Gomez et al. 2005) CmPP16 proteins are RNA-binding homologues of the RCNMV movement protein, which interacts with phloem proteins that are responsible for conducting CmPP16-1 but not CMPP16-2 to the roots. Thus, there are positive factors in $\mathrm{CC}$ and $\mathrm{SE}$ that ensure differential rootward transport of CmPP16 proteins (Aoki et al. 2002).

In contrast to evidence that certain viral and cellular proteins are positive effectors of phloem transport and unloading, there are also reports that selective phloem loading and unloading involves specific cellular barriers. The bundle sheath is reported to be a physical barrier to phloem loading of certain plant viruses and viroids (Fujita et al. 2000; Qi et al. 2004; Wang et al. 1998; Wintermantel et al. 1997). There are fewer plasmodesmata connections linking bundle sheath to $\mathrm{CC}$ than to mesophyll cells which may downregulate virus access to the phloem (Botha and Van Bel 1992). Studies of Cucumber mosaic virus (CMV), Cowpea mosaic virus (CPMV), and Tomato aspermy virus (TAV) indicated that these viruses enter major and minor veins in sink leaves but unloading is restricted in minor veins (Blackman et al. 1998; Silva et al. 2002; Thompson and GarciaArenal 1998). Experiments using the Tobacco etch virus (TEV) showed the importance of the HC-Pro-silencing suppressor protein for enabling virus entry and exit from SE, suggesting that the RNA-silencing machinery is also active in the CC-SE complex and may be a factor in virus entry and exit from the phloem (Cronin et al. 1995; Savenkov and Valkonen 2001). The 26S proteasome subunit RPN9 was recently identified as a 
factor which is partially regulated by auxin transport and brassinosteroid signaling and plays a role in vascular development and systemic transport of TMV and Turnip mosaic virus (TuMV). These data highlight the broad contribution of the $26 \mathrm{~S}$ proteasome to seemingly unrelated fundamental processes in the phloem (Jin et al. 2006). P-proteins synthesized in CC are also subject to proteolysis, which may serve to modulate protein levels in sieve tubes as well as limiting dispersal into surrounding parenchyma (Fisher et al. 1992). Thus, although there may be instances where restricted movement may be due to downregulation of plasmodesmata, there is mounting evidence that RNA-silencing machinery or proteolysis also contribute to the apparent restrictions in phloem unloading of certain nucleic acids and proteins (Cronin et al. 1995; Lopez et al. 2007).

In leaves, PVX, TMV, CPMV, and Potato virus $Y$ (PVY) are able to exit major veins but are restricted in minor veins, suggesting that cells neighboring major and minor veins may have different mechanisms to modulate protein and virus exit from the phloem (Ding et al. 1998; Roberts et al. 1997; Silva et al. 2002). The AtSUC2 and CmGAS1 promoters have been used to drive green fluorescent protein (GFP) expression in tobacco and Arabidopsis leaves to study phloem unloading as leaves undergo sink-source transition, and have provided evidence that phloem unloading of assimilates is restricted in minor veins (Haritatos et al. 2000; Imlau et al. 1999; Roberts et al. 2001; Stadler et al. 2005; Wright et al. 2003). Considering the large body of evidence linking minor vein development and photoassimilate partitioning with plasmodesmata transport abilities, and considering the work of Fisher and associates (1992) showing that protein synthesis in CC necessitated turnover to ensure interactions between sources and sinks, we asked the question: what happens to proteins which are synthesized in minor veins but are restricted from exiting into nonvascular tissues? There is no evidence to suggest that plasmodesmata connecting $\mathrm{CC}$ and surrounding cells are occluded before functional vein maturation; therefore, we undertook this study to determine whether protein turnover may also influence viral protein unloading.

The goal of this article is to identify factors which are positive and negative regulators of PVX phloem unloading. Research has shown that PVX TGBp1 and CP are required for

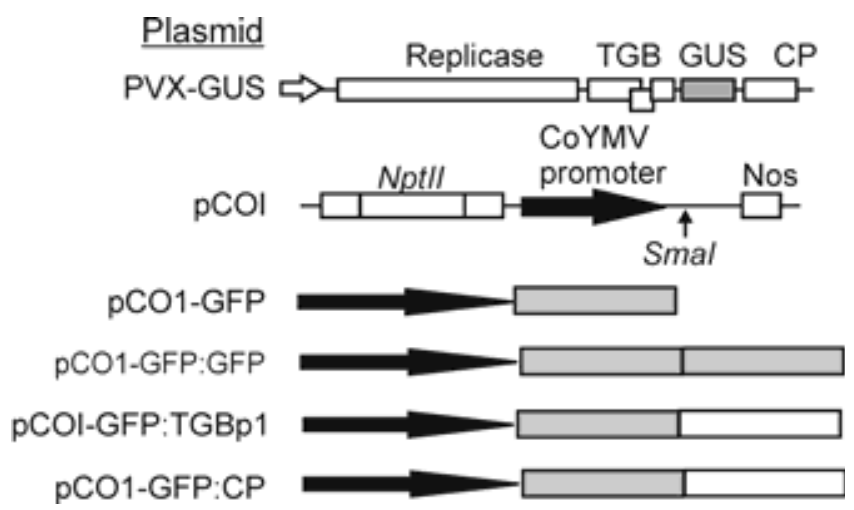

Fig. 1. Diagrammatic representation of PVX-GUS infectious clone is at the top of the figure. Open boxes represent PVX replicase, triple gene block (TGB), and coat protein (CP). The PVX TGB encodes three proteins named TGBp1, TGBp2, and TGBp3. Below the PVX-GUS depiction are representations of the pCOI constructs used in this study. The pCOI plasmid was obtained from B. Ding (Ohio State University) and contains the Commelina yellow mottle virus companion cell (CoYMV CC)-specific promoter (black arrow), and NptII containing an expression cassette for kanamycin resistance. There is a single SmaI restriction site where the transgenes were inserted. Four pCOI constructs containing green fluorescent protein (GFP) (gray box) alone or fused to GFP, TGBp1, or CP are shown. virus movement and likely contribute to a ribonucleoprotein complex that is translocated through the phloem (Lough et al. 2000, 2001; SantaCruz et al. 1998). In this study, we expressed GFP:TGBp1 and GFP:CP fusions from the CoYMV CC-specific promoter (Medberry and Olszewski 1993; Medberry et al. 1992). This is the first attempt to study phloem transport of PVX using a phloem-specific promoter. We chose the CoYMV promoter because it is expressed in seedlings as well as mature plants (Matsuda et al. 2002). The results presented in this study indicate that phloem-associated chlorenchyma provides a barrier to viral movement proteins exiting the phloem. PVX TGBp1 and CP appear to be positive effectors of phloem translocation; however, their unloading from the phloem depends upon interactions with viral RNA and may be regulated by $26 \mathrm{~S}$ proteasome.

\section{RESULTS}

\section{Preparation and characterization of transgenic plants.}

Transgenic Nicotiana benthamiana expressing GFP alone, GFP fused to the $5^{\prime}$ end of PVX TGBp1, CP, or GFP genes under the control of the CoYMV CC-specific promoter were prepared (Fig. 1). Transgenic lines contained the pCOI vector which has the CoYMV promoter and no added transgene. The resulting T0 lines were named GFP:TGBp1, GFP:CP, GFP:GFP, GFP, and COI (Fig. 1). The total number of plants regenerated on kanamycin-containing medium and which tested positive by polymerase chain reaction (PCR) for the promoter and transgene is shown in Table 1. Between 62 and $100 \%$ of T0 plants showed fluorescence in leaf veins (Fig. 2A, $\mathrm{B}$, and $\mathrm{C}$ ). Plants expressing GFP alone showed a very low level of fluorescence that was often difficult to discern (data not shown). Because the GFP:GFP expressing lines were brighter than GFP-expressing lines and are appropriate controls for other fusion proteins, further experiments were conducted with the GFP:GFP lines as primary controls.

$\mathrm{T} 1$ and $\mathrm{T} 2$ transformants were used for further experimentation. Fifteen T1 plants of each transgenic line were shown to

Table 1. Transformation and analysis of transgenic Nicotiana benthamiana plants

\begin{tabular}{lcccc}
\hline & \multicolumn{5}{c}{$\begin{array}{c}\text { No. of T0 plants } \\
\text { positive }\end{array}$} \\
\cline { 3 - 4 } Plant $^{\mathbf{y}}$ & No. of T0 individuals & PCR & GFP & PVX-GUS \\
\hline Susceptible & & & & \\
GFP:TGBp1 & 6 & 6 & 4 & + \\
GFP:TGBp2 & 5 & 5 & 5 & + \\
GFP:CP & 5 & 4 & 4 & + \\
GFP:GFP & 8 & 8 & 5 & + \\
GFP & 14 & ND & 12 & + \\
COI & 7 & 5 & 0 & + \\
Nontran & - & - & - & + \\
\hline
\end{tabular}

${ }^{\mathrm{x}}$ Number of $\mathrm{T} 0$ plants which were verified by polymerase chain reaction (PCR) to contain the Commelina yellow mottle virus promoter and transgene. Excised leaves were examined using epifluorescence microscopy to verify green fluorescent protein (GFP) expression in the veins. ND = not determined for T0. However, PCR was used to verify transgene in T1 GFP plants.

y $\mathrm{TGB}=$ triple gene block. Nontransgenic (Nontran) tobacco plants were used in each assay and produced negative results in PCR and GFP expression analyses. PVX-GUS inoculated nontransgenic tobacco plants were systemically infected whereas mock-inoculated plants showed no infection.

${ }^{\mathrm{z}}$ Potato virus $X$ - $\beta$-glucuronidase (PVX-GUS)-inoculated T1 and T2 individuals were analyzed for symptom development, GUS expression following histochemical staining, and by enzyme-linked immunosorbent assay to detect PVX virus in systemically infected leaves. All lines tested were PVX-GUS susceptible. 
be susceptible to PVX infection following inoculation with a version of PVX containing the $\beta$-glucuronidase gene (GUS) (Angell and Baulcombe 1995; Jefferson et al. 1987). Transgenic and nontransgenic (control) plants showed systemic symptoms between 5 and 7 days postinoculation and tested positive for PVX-GUS in the upper noninoculated leaves by histochemical staining for GUS activity and double-antibody sandwich enzyme-linked immunosorbent assay (DAS-ELISA) (Table 1). Mock-inoculated plants treated with buffer showed no symptoms and produced negative results in GUS and DAS-ELISA assays (data not shown).

\section{Phloem-associated expression}

\section{of transgenically expressed proteins.}

Cross-sections of excised transgenic $N$. benthamiana petioles (Fig. 3A, C, and E) and stems (Fig. 3B, D, and F) show the bicollateral vasculature (Metcalfe and Chalk 1979) and were examined to initially assess the extent of GFP fluorescence in vascular bundles. GFP:TGBp1, GFP:CP, and GFP:GFP fluorescence is seen in the internal and external phloem, which is expected of proteins expressed from the CoYMV promoter (Fig. 3, arrows). The central xylem vessels show significant yellow autofluorescence in all live sections, which could conceal green fluorescence in neighboring photosynthetic vascular cells (i.e., chlorenchyma) (Hibberd and Quick 2002).

Importantly, during the initial screening, some T0 N. benthamiana lines lacked fluorescence in SE although containing fluorescence in CC (Ding et al. 2003; Itaya et al. 2002), T1 and T2 progeny were further screened to identify lines in which fluorescence could be seen in both $\mathrm{CC}$ and $\mathrm{SE}$ to ensure that transgenic proteins studied here were phloem mobile (Fig. 4). These selected lines were used for further investigations of protein transport through the vasculature. Immunoblot analysis of selected lines confirmed that fusion proteins were intact (data not shown).

To determine whether transgenically expressed proteins are mobile through sieve tubes, nontransgenic scions were grafted to transgenic or virus-infected rootstocks. Fluorescence was analyzed 14 days post-grafting and fluorescence was seen in stem sections above the graft union employing GFP:GFP,
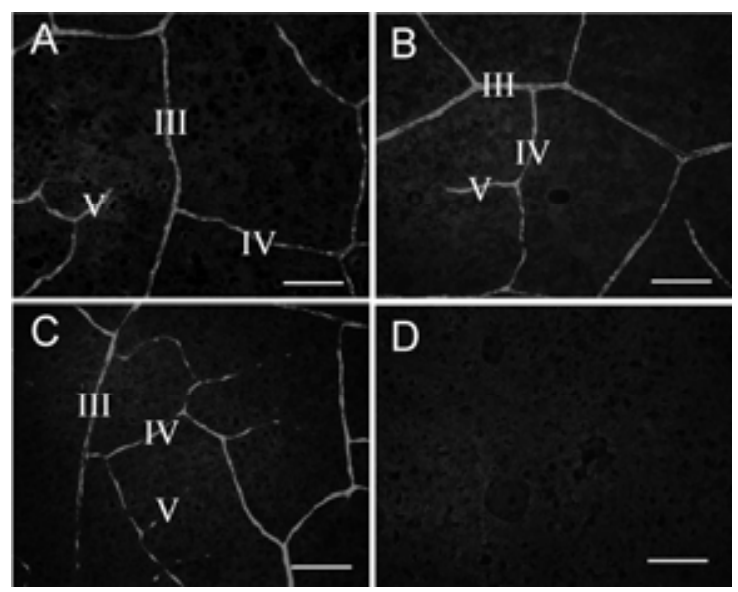

Fig. 2. Representative images of T0 transgenic Nicotiana benthamiana leaves. Fluorescence was seen in young and fully expanded leaves. A, Green fluorescent protein:triple gene block (GFP:TGB)p1; B, GFP:coat protein (CP); C, GFP:GFP; D, COI. Class III, IV, and V veins are indicated in $\mathrm{A}, \mathrm{B}$, and $\mathrm{C}$. Vein classes are defined by their branching patterns and function in assimilate and macromolecular transport (Cheng et al. 2000; Nelson and Van Bel 1998; Roberts et al. 1997). Class III veins are also referred to as "release" phloem involved in unloading assimilates. Class IV and V veins are "collection" phloem contributing to phloem loading (Van Bel 1996). Bars represent $200 \mu \mathrm{m}$.
GFP:TGBp1, and GFP:GFP rootstocks. GFP fluorescence was low in scions and we suspected that this was due to complications such as slow healing of the graft union, early flowering of grafted plants, or failure of grafted plants to continue to grow beyond the 14 days post-grafting.

To better study phloem mobility of the GFP fusion proteins, we also prepared transgenic $N$. tabacum expressing GFP:TGBp1, GFP:CP, GFP:GFP, and GFP. Nontransgenic $N$. tabacum scions were grafted to transgenic and virus-infected rootstocks. Fluorescence was analyzed microscopically at various times post-grafting and was first seen at 28 days postgrafting in the nontransgenic stem approximately $4 \mathrm{~cm}$ above the graft union. $N$. tabacum plants continued to grow beyond this time, making it possible to make more extended observations before flowering occurred (Table 2). Nontransgenic scions grafted to PVX-GUS-infected tobacco also showed typical mosaic symptoms at 3 weeks after grafting (Table 2). In addition, nontransgenic scions were grafted to nontransgenic tobacco rootstocks and the phloem-mobile 5(6)-carboxyfluorescein diacetate $(\mathrm{CF})$ dye was applied to a leaf petiole on the

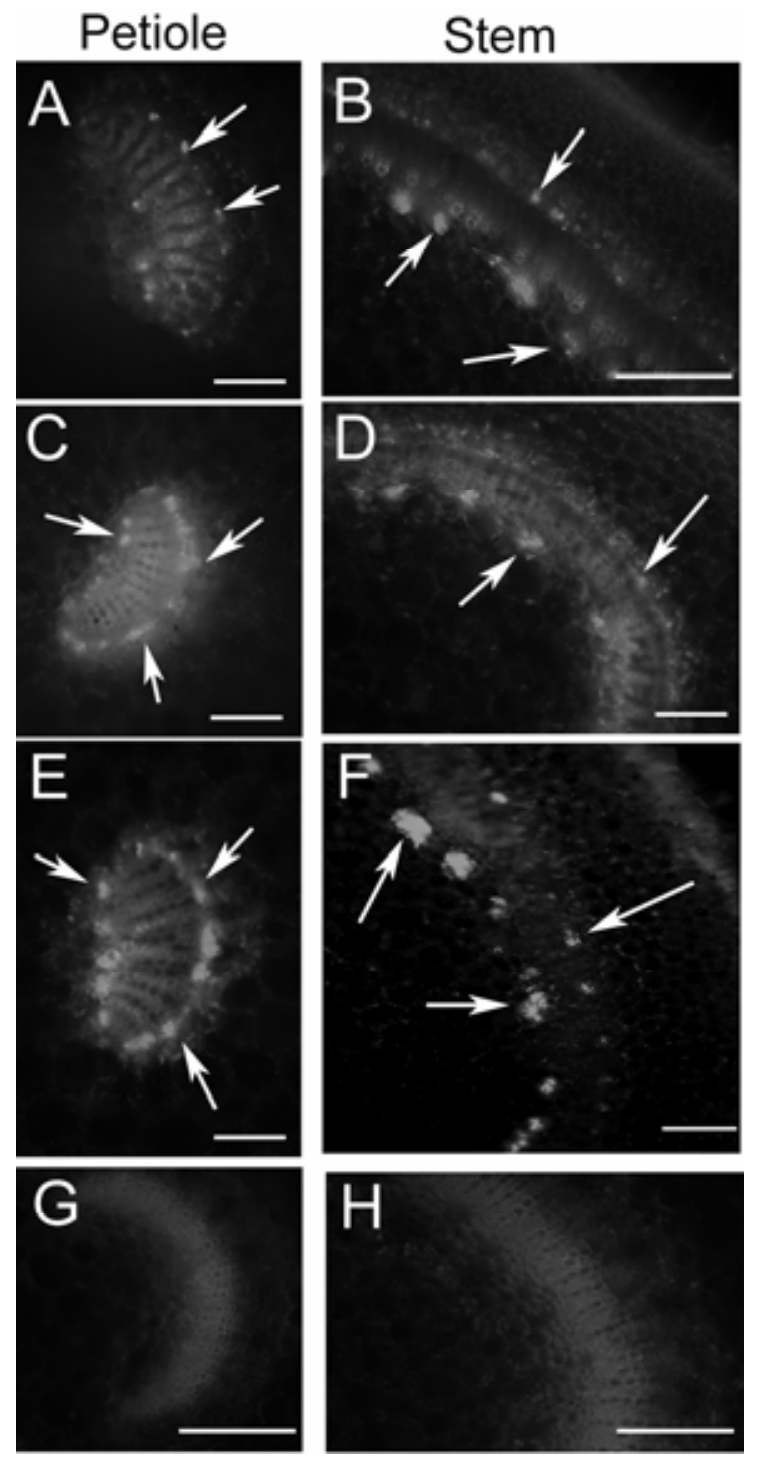

Fig. 3. Representative cross-sections of Nicotiana benthamiana stems and petioles showing that fluorescence is restricted to the phloem. Arrows point to examples of green fluorescent protein (GFP) fluorescence in internal and external phloem. Internal phloem is toward the left in petiole and stem sections. $\mathbf{A}$ and B, GFP: TGBp1; $\mathbf{C}$ and D, GFP:CP; $\mathbf{E}$ and F, GFP:GFP; $\mathbf{G}$ and $\mathbf{H}$, nontransgenic tobacco. Bars represent $200 \mu \mathrm{m}$. 
rootstock (at 28 days after grafting) and was seen in scion leaves within $6 \mathrm{~h}$ after application, verifying that the grafts succeed in creating a continuum between phloem strands. As a negative control, nontransgenic $N$. tabacum scions were grafted to COI rootstocks and no fluorescence was detected in stem sections above the graft union. The comparably slower movement of GFP fusion proteins suggests that healing of the graft unions in $N$. benthamiana and $N$. tabacum was not particularly efficient or rapid. Itaya and associates (2002) reported that CMV 3a:GFP fusions expressed from the CoYMV promoter in $N$. tabacum root stocks move across the graft union and can be detected in nontransgenic scions approximately 2 weeks postgrafting. GFP and each PVX fusion moves comparably slower in $N$. tabacum than 3a:GFP. The slow movement also could explain the low levels of fluorescence seen in scion tissue of grafted $N$. benthamiana at 14 days postinoculation. Thus, protein movement was slow in both $N$. tabacum- and $N$. benthamiana-grafted plants, but the $N$. benthamiana- grafted plants began to flower earlier than N. tabacum, and this is an important developmental change that likely impacted photoassimilate partitioning and phloem transport. When a plant flowers, resources are redirected to the growing points and this may impact our observations in the $N$. benthamiana experiments.

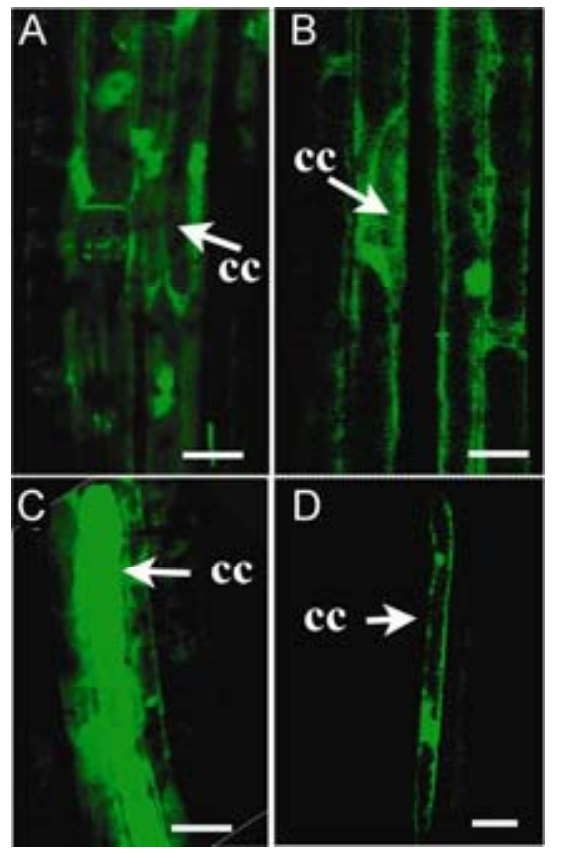

Fig. 4. Longitudinal views of leaf veins showing A, GFP:TGBp1; B, GFP: CP; C, GFP:GFP in companion cell (CC)-sieve element complex phloem; and $\mathbf{D}$, example of transgenic tobacco line showing GFP:CP fluorescence restricted to a CC. Bars represent $20 \mu \mathrm{m}$.

Table 2. Graft transmission of transgenically expressed fusion proteins ${ }^{2}$

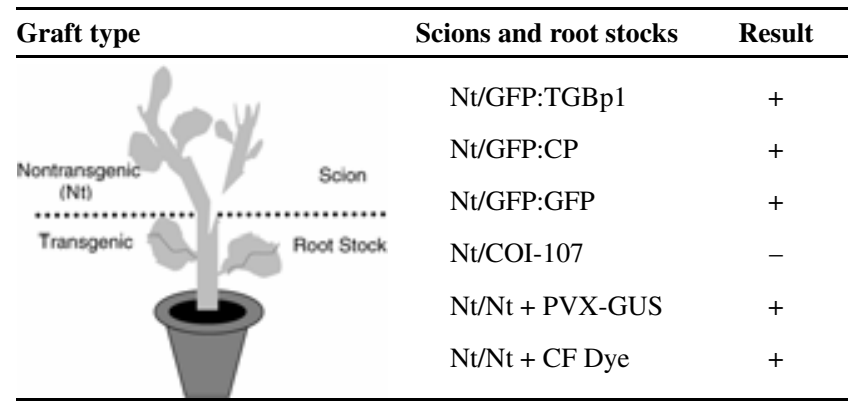

${ }^{\mathrm{z}}$ Results from five plants each. $\mathrm{Nt}=$ nontransgenic, $\mathrm{GFP}=$ green fluorescent protein, $\mathrm{TGB}=$ triple gene block, and $\mathrm{CP}=$ coat protein.

\section{GFP fusions are restricted to}

the vasculature in transgenic petioles and stems.

The petiole provides bidirectional (Trip and Gorham 1968) communication between the leaf and stem; therefore, experiments using petioles provide the best opportunity to view pro-
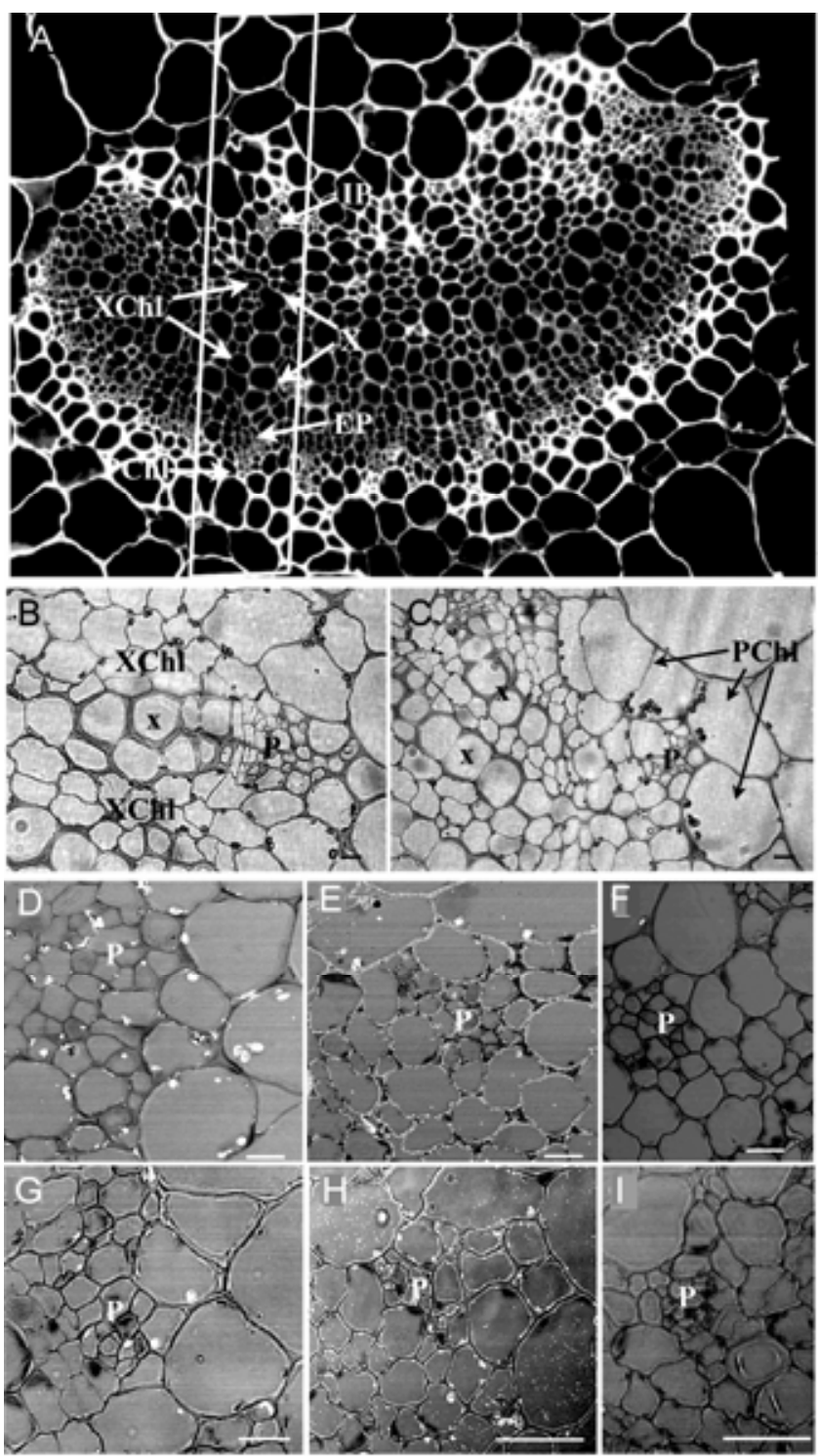

Fig. 5. Confocal images of immunolabeled LR-White embedded petiole cross-sections. A, Cross-section of GFP:TGBp1 sample shows detailed structure of petiole similar to the detailed drawing of the vascular arc of tobacco midvein presented by Avery (1933). The white box represents a field ( 1.2 by $0.1 \mathrm{~mm}$ ) scored in Table 2 for fluorescence in vascular tissue. IP, internal phloem; EP, external phloem; X, xylem; XChl, xylem-associated chlorenchyma; PChl, phloem-associated parenchyma. $\mathbf{B}$ and $\mathbf{C}$, Images of GFP:TGBp1 sections stained with IKI shows black starch granules, and counterstained with Safranin-O which highlights cell walls. D through I, Internal phloem (P) surrounded by the larger starch containing chlorenchyma described by Hibberd and Quick (2002). Sections treated with TGBp1 antiserum include D, GFP:TGBp1; E, PVXGUS-infected Nicotiana benthamiana; and F, healthy $N$. benthamiana petioles. Sections treated with PVX coat protein (CP) antiserum include G, GFP:CP; H, PVX-GUS-infected $N$. benthamiana; and I, healthy $N$. benthamiana petioles. Bars represent $200 \mu \mathrm{m}$. Nontransgenic samples treated with TGBp1 and CP antisera show minimal labeling (Table 3). The proportion of transgenic and virus-infected cells showing positive results were significantly greater than nontransgenic cells. We were unable to conduct immunofluorescence labeling using GFP antisera due to high background labeling which we were unable to rectify. Immunofluorescence label appears white. 
tein exit from the phloem regardless of the direction of bulk flow translocation. Furthermore, protein unloading from the phloem into chlorenchyma surrounding the xylem and phloem in petioles has never been characterized for $N$. benthamiana plants. Because these cells are photosynthetically active, potassium iodide staining shows starch granules in chlorenchyma between xylem strands, surrounding the phloem, and just below the cortex in $N$. benthamiana petioles (Fig. 5B and C). The dimensions of the photosynthetic cells between the phloem and cortex are larger than those of neighboring xylem vessels and resemble the starch sheath cells of the stem and the bundle sheath cells of the leaf (Hibberd and Quick 2002; Klotz et al. 1998; Paramonova et al. 2002). In leaves, the frequency of plasmodesmata connections between CC and bundle sheath cells is less than the connections between neighboring vascular parenchyma (Botha and Van Bel 1992). If the larger chlorenchyma cells neighboring phloem are functionally similar to bundle sheath cells in the leaf, then we expect to see less movement of proteins into these cells than movement of proteins between neighboring xylem-associated chlorenchyma. Evidence that the photosynthetic pathway in the vascular-associated chlorenchyma in $N$. benthamiana petioles and stems parallels bundle sheath cells in leaves led us to investigate the possibility that chlorenchyma neighboring the phloem in petioles provides the same barrier to protein unloading from the phloem into nonvascular tissues.

In agreement with evidence showing phloem-specific expression of GFP, immunofluorescence labeling of transgenic $N$. benthamiana samples detected GFP:TGBp1 (Fig. 5D) and GFP:CP (Fig. 5G) in the phloem. To quantify the extent of protein movement from the phloem into neighboring cells, sections were imaged and 1.2-by-0.1-mm fields transecting the petiolar vascular arc were scored (Fig. 5A; Table 3). In all, 80 to 100 fields treated with each antiserum were scored for fluorescence in each cell type: internal or external $\mathrm{CC}$, internal or external SE, chlorenchyma neighboring internal or external phloem, and chlorenchyma neighboring xylem vessels. GFP:TGBp1 and GFP:CP were distributed throughout the phloem and chlorenchyma cells (Table 3). For GFP:TGBp1, between 90 and $95 \%$ of CC-SE complexes in the internal and external phloem showed immunofluorescence labeling. For GFP:CP-transgenic $N$. benthamiana petiole sections, $58 \%$ of fields showed immunofluorescence labeling in internal and external phloem. The level of immunofluorescence labeling in chlorenchyma located between xylem vessels was $80 \%$, indicating extensive movement of GFP:TGBp1 between cells within the vascular arc. This was contrasted by GFP:CP, for which only $12 \%$ of chlorenchyma neighboring xylem vessels showed immunolabeling, indicating that GFP:TGBp1 has greater mobility than GFP:CP in these cells. However, for both GFP:TGBp1- and GFP:CP-transgenic $N$. benthamiana petioles, only $12 \%$ of phloem-associated chlorenchyma located between the phloem and cortex showed labeling, which was three- to sixfold less than the neighboring phloem (Table 3 ). These data indicate that $N$. benthamiana petioles contain a population of chlorenchyma cells neighboring the phloem which provides a barrier to protein movement into the cortex much the way that the bundle sheath provides a barrier to protein movement out of the phloem in $N$. benthamiana leaves (Botha and Van Bel 1992; Thompson and Garcia-Arenal 1998).

Immunolabeling was conducted using sections of nontransgenic PVX-GUS-infected $N$. benthamiana petioles and, as in the transgenic samples, TGBp1 (88 to $100 \%)$ was higher than $\mathrm{CP}(50 \%)$ in the phloem (Fig. 5E and H). Although there was less labeling in phloem-associated chlorenchyma, the values obtained for virus-infected sections were significantly higher than transgenic samples, suggesting that PVX-GUS provides activities needed to enable TGBp1 and CP to exit the phloem and move toward the cortex.

\section{Proteins exit from the phloem \\ into surrounding nonvascular tissues in leaves.}

$N$. benthamiana leaves contain a network of veins classified as class I to $\mathrm{V}$ and grouped into major (class I to III veins) or minor (class IV and V veins) veins according to their branching patterns and function in photo assimilate and macromolecular transport (Cheng et al. 2000; Nelson and Van Bel 1998; Roberts et al. 1997). The internal phloem extends from the petiole into the midrib which is also defined as class I veins. Class II and III veins are successive branches (Avery 1933; Roberts et al. 1997). Class IV and V veins are minor veins which develop during leaf expansion and have been reported to function only for uptake of photoassimilates and fluorescent molecules in source tissues (Fig. 1).

Fluorescence due to GFP:TGBp1, GFP:CP, and GFP:GFP was generally restricted in all major and minor vein classes of

Table 3. Immunofluorescence labeling of transgenic, nontransgenic, and virus-infected petiole cross-sections

\begin{tabular}{|c|c|c|c|c|c|c|}
\hline \multirow[b]{2}{*}{ Genotype $^{y}$} & \multirow[b]{2}{*}{$\operatorname{Sera}^{\mathrm{z}}$} & \multirow[b]{2}{*}{ Fields } & \multicolumn{4}{|c|}{ Percentage of fields with fluorescent signals (percent positive) ${ }^{x}$} \\
\hline & & & Int phloem & Ext phloem & Xyl chlor & Phloem chlor \\
\hline \multicolumn{7}{|l|}{ Experiment 1} \\
\hline GFP:TGBp1 & TGBp1 & 80 & $72(90 a)$ & $76(95.0 \mathrm{a})$ & 80 (100 a) & $12(15.0 \mathrm{~b})$ \\
\hline Nontransgenic + PVX & TGBp1 & 80 & $71(88.8 \mathrm{a})$ & $80(100 a)$ & $55(68.8 \mathrm{~b})$ & $38(47.5 \mathrm{a})$ \\
\hline Nontransgenic & TGBp1 & 80 & $28(35.0 \mathrm{~b})$ & $24(30.0 \mathrm{~b})$ & $19(23.8 \mathrm{c})$ & $8(10.0 \mathrm{c})$ \\
\hline GFP:TGBp1 & Buffer & 10 & $0(0.0 \mathrm{c})$ & $0(0.0 \mathrm{c})$ & $0(0.0 \mathrm{~d})$ & $0(0.0 \mathrm{c})$ \\
\hline Nontransgenic & Buffer & 25 & $0(0.0 \mathrm{c})$ & $0(0.0 \mathrm{c})$ & $0(0.0 \mathrm{~d})$ & $0(0.0 \mathrm{c})$ \\
\hline \multicolumn{7}{|l|}{ Experiment 2} \\
\hline GFP:CP & $\mathrm{CP}$ & 100 & $58(58.0 \mathrm{a})$ & $58(58.0 \mathrm{a})$ & $12(12.0 \mathrm{~b})$ & $12(12.0 \mathrm{~b})$ \\
\hline Nontransgenic + PVX & $\mathrm{CP}$ & 100 & $50(50.0 a)$ & $50(50.0 \mathrm{a})$ & $40(40.0 \mathrm{a})$ & $34(34.0 \mathrm{a})$ \\
\hline Nontransgenic & $\mathrm{CP}$ & 100 & $6(6.0 \mathrm{~b})$ & $3(3.0 \mathrm{~b})$ & $0(0.0 \mathrm{c})$ & $4(4.0 \mathrm{c})$ \\
\hline GFP:CP & Buffer & 15 & $0(0.0 \mathrm{~b})$ & $0(0.0 \mathrm{~b})$ & $0(0.0 \mathrm{c})$ & $0(0.0 \mathrm{c})$ \\
\hline Nontransgenic & Buffer & 25 & $0(0.0 \mathrm{~b})$ & $0(0.0 \mathrm{~b})$ & $0(0.0 \mathrm{~b})$ & $0(0.0 \mathrm{c})$ \\
\hline
\end{tabular}

${ }^{\mathrm{x}}$ Two fields $(1.2$ by $0.1 \mathrm{~mm})$ per section were scored for fluorescence occurring in the vasculature. Values represent the number of fields showing fluorescence in the internal (Int) phloem, external (Ext) phloem, xylem-associated chlorenchyma (Xyl chlor), and phloem-associated chlorenchyma (Phloem chlor). Values in parentheses indicate the percentage of fields that were positive for fluorescence in each location. Statistical analysis was conducted down each column for each sera to demonstrate that triple gene block (TGB)p1 or coat protein (CP) sera significantly labeled the transgenic plants and virus-infected plants. Values followed by the same letter with in a column and an experiment are not significantly different at 5\% probability. Labeling was minimal in nontransgenic tissue or samples treated with buffer.

${ }^{\mathrm{y}} \mathrm{GFP}=$ green fluorescent protein and $\mathrm{PVX}=$ Potato virus $X$.

${ }^{\mathrm{z}}$ PVX-GUS-infected samples were treated with PVX TGBp1 or CP antisera. Buffer = sections treated with buffer and secondary antisera. Nicotiana benthamiana control is listed twice for statistical comparison. 
each transgenic $N$. benthamiana line analyzed (Table 4; Fig. 6A, D, and G). Following inoculation with PVX-GUS, bright fluorescence was seen in mesophyll or epidermal cells along major and minor veins in the upper systemically infected leaves of 16 to $27 \%$ GFP:TGBp1 and GFP:CP N. benthamiana plants (Fig. 6C and F). Fluorescence was faint beyond a single file of cells surrounding the veins of systemically infected
GFP:TGBp1 and GFP:CP leaves. Thus, experiments conducted in $N$. benthamiana leaves and petioles both demonstrate that GFP:TGBp1 and GFP:CP exit from the phloem is markedly improved by the presence of PVX-GUS (Table 4). Because GFP:GFP failed to exit the phloem, the best explanation is that TGBp1 and CP specifically interact with PVX-GUS for phloem export (Fig. 6I). Plants were also inoculated with puri-

Table 4. Green fluorescent protein (GFP) fluorescence in leaves treated with virus or proteasome inhibitors ${ }^{\mathrm{y}}$

\begin{tabular}{|c|c|c|c|c|c|}
\hline \multirow[b]{2}{*}{ Transgenic lines $^{\mathrm{z}}$} & \multirow[b]{2}{*}{ No. of plants } & \multirow[b]{2}{*}{ Virus } & \multirow[b]{2}{*}{ Proteasome inhibitors } & \multicolumn{2}{|c|}{ No. $(\%)$ of plants showing protein unloading in veins } \\
\hline & & & & Major veins & Minor veins \\
\hline GFP:TGBp1 & 18 & - & - & $0(0)$ & $0(0)$ \\
\hline GFP:TGBp1 & 18 & $\mathrm{P}$ & - & $3(16)$ & $5(27)$ \\
\hline GFP:TGBp1 & 5 & - & + & $5(100)$ & $5(100)$ \\
\hline GFP:TGBp1 & 5 & $\mathrm{P}$ & + & $5(100)$ & $5(100)$ \\
\hline GFP:TGBp1 & 7 & $\mathrm{~T}$ & - & $0(0)$ & $0(0)$ \\
\hline GFP:CP & 18 & - & - & $0(0)$ & $0(0)$ \\
\hline GFP:CP & 18 & $\mathrm{P}$ & - & $3(16)$ & $5(27)$ \\
\hline GFP:CP & 7 & - & + & 7 (100) & 7 (100) \\
\hline GFP:CP & 5 & $\mathrm{P}$ & + & $5(100)$ & $5(100)$ \\
\hline GFP:CP & 7 & $\mathrm{~T}$ & - & $0(0)$ & $0(0)$ \\
\hline GFP:GFP & 18 & - & - & $0(0)$ & $0(0)$ \\
\hline GFP:GFP & 18 & $\mathrm{P}$ & - & $0(0)$ & $0(0)$ \\
\hline GFP:GFP & 7 & - & + & 7 (100) & $7(100)$ \\
\hline GFP:GFP & 5 & $\mathrm{P}$ & + & $5(100)$ & $0(0)$ \\
\hline GFP:GFP & 7 & $\mathrm{~T}$ & - & $5(100)$ & $0(0)$ \\
\hline
\end{tabular}

${ }^{\mathrm{y}}$ Fifteen healthy PVX-GUS (P)- or Tobacco mosaic virus (T)-infected plants were analyzed for protein unloading from major and minor leaf veins (class I to V) into surrounding tissues. Leaf surfaces and cross-sections through the veins were analyzed using epifluorescence microscopy. Then, entire leaves were infiltrated with a cocktail of $26 \mathrm{~S}$ proteasome inhibitors and two to four segments per leaf were analyzed for the accumulation of fluorescence in cells surrounding the veins. The results were consistent in all leaf segments analyzed.

${ }^{\mathrm{z}} \mathrm{TGB}=$ triple gene block and $\mathrm{CP}=$ coat protein.

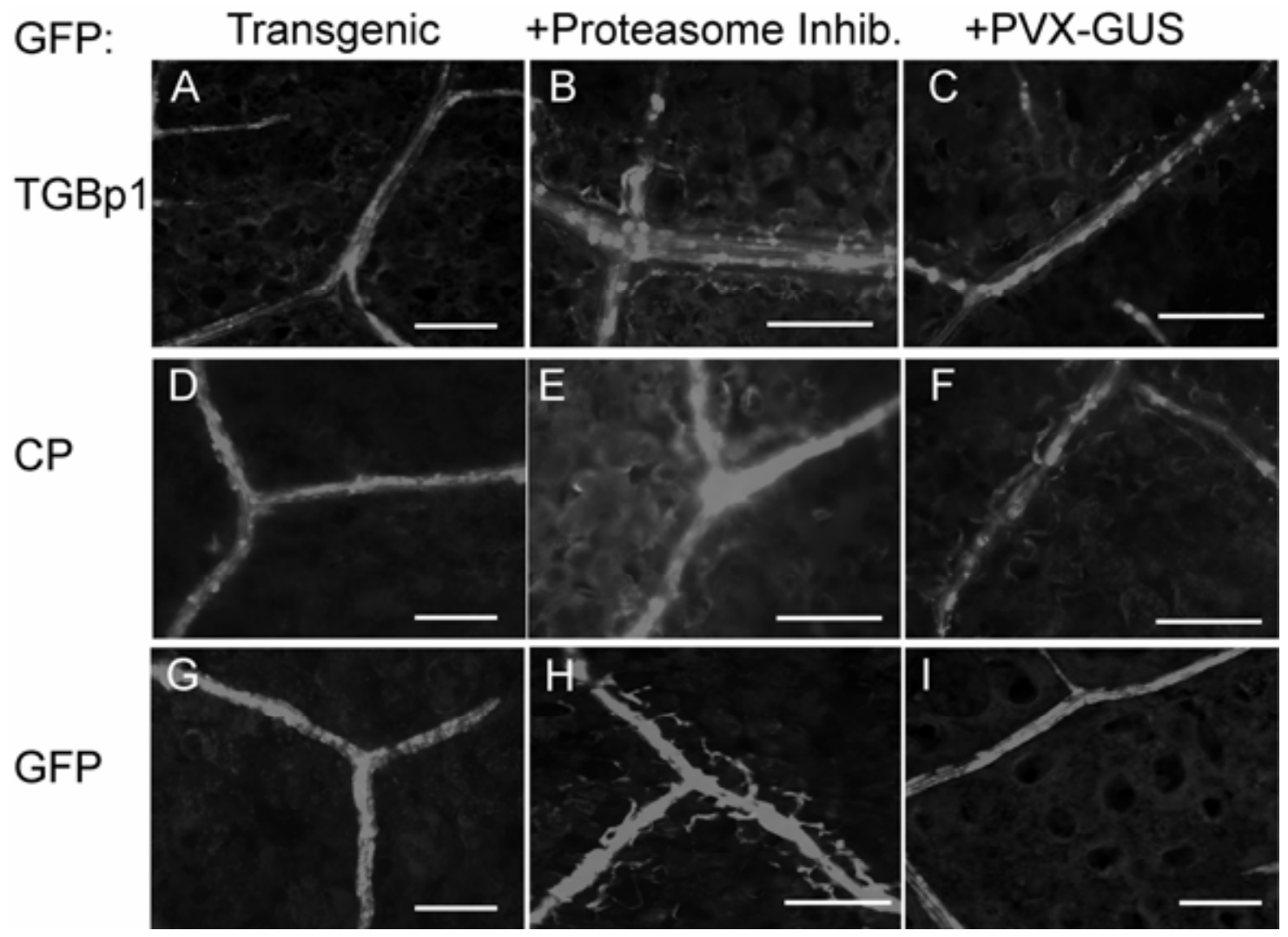

Fig. 6. Epifluorescence images of transgenic Nicotiana benthamiana leaves. The left column shows leaves infiltrated with Murashige and Skoog (MS) medium. Fluorescence is restricted to the veins. Fluorescence was also restricted to the veins of healthy, untreated plants, indicating that infiltration with MS medium did not impact protein exiting the veins (data not shown). The middle column shows systemically infected leaves infiltrated with MS medium plus $26 \mathrm{~S}$ proteasome inhibitors. The last column shows leaves isolated from Potato virus X- $\beta$-glucuronidase (PVX-GUS)-infected plants. Green fluorescent protein (GFP)-fused transgenes are indicated on the left of each row and treatments are indicated above each column A through C, GFP:triple gene block (TGB)p1; D through F, GFP:coat protein (CP); and G through I, GFP:GFP. Bars represent $200 \mu \mathrm{m}$. 
fied TMV virus $(10 \mu \mathrm{g} / \mathrm{ml})$ to determine whether GFP fusions can exit the phloem if a heterologous virus is present. TMV had no impact on the ability of GFP:GFP, GFP:TGBp1, or GFP:CP to exit the phloem (Table 4).

However, considering the low proportion of transgenic $N$. benthamiana plants showing GFP:TGBp1 and GFP:CP unloading from the phloem, there appears to be a mechanism that is preventing a majority of the fusion proteins from exiting veins regardless of the presence of PVX-GUS. Although there are many possible explanations for the lack of protein unloading from the phloem, we considered the possibility that the hosts' degradation machinery may be limiting protein exit from the phloem. This is based on evidence presented by Aoki and associates (2005) suggesting that cellular degradation machinery may impact vascular unloading of plant proteins, and reports that the $26 \mathrm{~S}$ proteasome regulates systemic spread of TMV and TuMV (Jin et al. 2006; Ju et al. 2005; Reichel and Beachy 2000).

\section{Proteasome inhibitors impact fluorescence accumulation in leaves.}

Healthy and PVX-GUS-infected transgenic N. benthamiana leaves were infiltrated with a cocktail of $50 \mu \mathrm{M} \mathrm{MG-115}$ and MG-132 proteasome inhibitors. Leaves were examined 18 to $24 \mathrm{~h}$ later and bright green fluorescence was in one or two files of cells outside the veins in 100\% of GFP:TGBp1 and GFP:GFP plants (Table 4; Fig. 6B and I). In contrast, GFP:CP fluorescence spread extensively through mesophyll cells surrounding major and minor veins, indicating that $\mathrm{PVX} \mathrm{CP}$ is a better substrate for the $26 \mathrm{~S}$ proteasome. In the epidermis, GFP:CP fluorescence was more pronounced in one or two files of cells along the veins and fluorescence spread further through the mesophyll (Fig. 6E). Fluorescence in nonvascular cells was greater in GFP:CP than GFP:TGBp1 leaves treated with the same cocktail of proteasome inhibitors. Although GFP:CP may be a better target for the $26 \mathrm{~S}$ proteasome than GFP:TGBp1 or GFP:GFP, the combined data indicate that the cellular degradation machinery plays a role in selective unloading of proteins from leaf veins.

We also compared fluorescence accumulation in PVX-GUSinfected GFP:TGBp1, GFP:CP, and GFP:GFP leaves treated with medium or $26 \mathrm{~S}$ proteasome inhibitors and the results were similar, indicating that the combination of virus and inhibitors did not have an additive effect on protein exit from the phloem (data not shown; Table 4). One explanation is that during infection, PVX has the ability to protect its own proteins from $26 \mathrm{~S}$ proteasomal degradation as they exit the phloem into nonvascular tissues.

Immunoblot analysis with GFP antisera was used to compare fusion protein accumulation in leaf extracts treated with

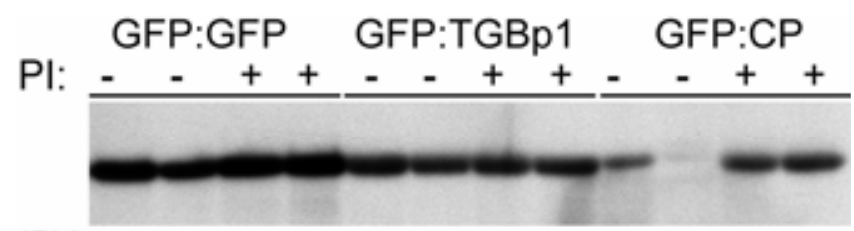

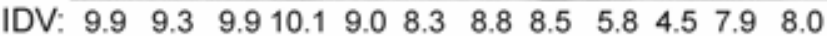

Fig. 7. Immunoblot analysis of leaf extracts from transgenic tobacco. Blots were probed with green fluorescent protein (GFP) antisera to detect fusion proteins. GFP:triple gene block (TGB)p1, GFP:coat protein (CP), and GFP:GFP (labeled GFP:G) are similar sizes and comigrated on the gel. Samples were taken from leaves treated with Murashige and Skoog (MS) medium (-) or with a cocktail of $26 \mathrm{~S}$ proteasome inhibitors in MS medium $(\mathrm{PI} ;+)$. Integrated density values (IDV) are presented below each lane as the percent total density values determined for all lanes. Western shows that PItreated samples accumulate to higher levels than untreated samples. inhibitors or medium alone. Equal quantities of protein were loaded in each lane. In repeated experiments, the amount of GFP:CP in transgenic leaves was enhanced in extracts taken following treatment with a cocktail of $26 \mathrm{~S}$ proteasome inhibitors (Fig. 7). Densitometry was used to quantify each band and the values are presented as a percentage of the total density in all lanes. The integrated density values among GFP:GFP and GFP:TGBp1 samples treated with medium or proteasome inhibitors were similar. Thus, movement of GFP:TGBp1 from veins into neighboring epidermal cells is directly controlled by the $26 \mathrm{~S}$ proteasome without impacting gene expression or overall GFP:TGBp1 accumulation in the initial CC. On the other hand GFP:CP accumulation significantly increased due to the $26 \mathrm{~S}$ proteasome inhibitor cocktail and this is reflected in the extensive movement of GFP:CP from the veins into more distant mesophyll cells seen in Figure 6E. The proteasome inhibitors had a greater effect on GFP:CP accumulation and cell-to-cell spread than GFP:TGBp1 or GFP:GFP. The different responses to the $26 \mathrm{~S}$ proteasome inhibitors suggest that the $26 \mathrm{~S}$ proteasome specifically alters GFP:CP accumulation and generally impacts protein unloading from the phloem in major and minor veins.

\section{DISCUSSION}

This study is the first to employ a CC-specific promoter to investigate the requirements for PVX vascular transport. In transgenic leaves, GFP:TGBp1, GFP:CP, and GFP:GFP accumulated in major and minor veins but were restricted from exiting into epidermal or mesophyll cells under normal conditions. Wright and associates (2003) used the AtSUC2 promoter to express GFP in $N$. benthamiana, and determined when gene expression occurred and when GFP unloaded from the veins into surrounding nonvascular tissues during plant development. These experiments showed that protein exits major but not minor veins, indicating differential regulation of transport from major and minor veins. Although it is possible that plasmodesmata connecting to protophloem in developing minor veins are nonfunctional or are laid down after cells have matured, this explanation seems implausible because plasmodesmata are crucial for cross talk that occurs between neighboring cells during development and differentiation. Because the AtSUC2 promoter is turned on when sucrose synthesis begins in $\mathrm{CC}$, experiments conducted using this promoter link plasmodesmata function to sucrose metabolism (Imlau et al. 1999; Meyer et al. 2004; Stadler et al. 2005; Wright et al. 2003). Thus, our experiments were undertaken using the CoYMV promoter to determine whether plasmodesmata transport from minor veins can be viewed when expression is uncoupled from sucrose synthesis and transport. This strategy provided an alternative approach to studying selective plasmodesmata transport of proteins from major and minor veins. Studies using the CoYMV and AtSUC2 promoter identified similar restrictions for proteins exiting minor veins in leaves; therefore, it is likely that there is a specific barrier to protein unloading that may be independent of development (Itaya et al. 2002; Matsuda et al. 2002). In Plants inoculated with PVXGUS or treated with a cocktail of $21 \mathrm{~S}$ and $26 \mathrm{~S}$ proteasome inhibitors showed a greater movement of fluorescence into neighboring nonvascular tissues from major and minor veins (Figs. 6 and 7), indicating that plasmodesmata neighboring these veins are functional for export as well as import. Evidence of increased protein unloading from the phloem in the presence of PVX-GUS supports prior a model proposed by Lough and associates $(2000,2001)$, indicating that a ribonucleoprotein complex is more likely to exit the phloem than the viral proteins themselves. 
Using plants selected for fluorescence in CC-SE complexes, we found that GFP:TGBp1 and GFP:CP exit the CC-SE complex into neighboring vascular chlorenchyma in petioles. GFP:TGBp1 moved more extensively than GFP:CP into chlorenchyma neighboring xylem vessels. Several reports have documented that TGBp1 or GFP:TGBp1 increases plasmodesmata conductance relative to GFP alone and this enables more extensive movement of the fusion protein or fluorescent dextran beads (Howard et al. 2004; Lough et al. 1998; Schoenknecht et al. 2008). Because PVX CP does not have this ability to increase plasmodesmata conductance (Krishnamurthy et al. 2002; SantaCruz et al. 1998), the different abilities of GFP:TGBp1 and GFP:CP to move within the vascular bundle may be a consequence of their different abilities to act on plasmodesmata.

In PVX-infected petioles, CP accumulation was higher than GFP:CP in vascular chlorenchyma. This could be due to transdominant effects of other PVX proteins (such as TGBp1) or viral RNA. PVX TGBp1 has the ability to induce plasmodesmata gating necessary for virus cell-to-cell movement and contributes to a ribonucleoprotein complex involving $\mathrm{CP}$ and vRNA that moves from cell to cell and through the phloem (Lough et al. 2000, 2001; Rodionova et al. 2003). Thus, the increased CP accumulation in PVX-GUS-infected chlorenchyma represents either movement of the ribonucleoprotein complex between cells or TGBp1 gating plasmodesmata to enable transfer of $\mathrm{CP}$ between cells.

Considering that Hibbard and Quick (2002) described the similarities between the photosynthetic capabilities of bundle sheath cells and chlorenchyma bordering phloem and cortex in C3 to C4 intermediate plants, data obtained in this study demonstrate that chlorenchyma bordering the vascular bundle in $N$. benthamiana petioles also resemble leaf bundle sheath cells in their ability to restrict proteins exiting the phloem. Phloemassociated chlorenchyma provides a barrier to GFP:TGBp1 and GFP:CP transport into the cortex (Fig. 5C). PVX-GUS has a greater ability to surpass this barrier than the individual transgenically expressed proteins (Table 3), and this is paralleled in leaves where PVX-GUS facilitated movement of GFP:TGBp1 and GFP:CP into mesophyll and epidermal cells. When we consider the many studies reporting the bundle sheath as a barrier to the exchange of virus between mesophyll and phloem (Fujita et al. 2000; Qi et al. 2004; Wang et al. 1998; Wintermantel et al. 1997), evidence presented in this study supports the hypothesis that the chlorenchyma in $N$. benthamiana petioles provides a similar transport barrier between the phloem and cortex and indicates further interesting parallels between these cells. Botha and Van Bel (1992) quantified plasmodesmata distribution from the mesophyll to sieve tube and found that so few plasmodesmata connect $\mathrm{CC}$ to neighboring bundle sheath or vascular parenchyma that $\mathrm{CC}$ often seem to be symplastically isolated from these neighboring cells. It would be worth conducting a similar analysis in $N$. benthamiana petioles to determine whether the connections between $\mathrm{CC}$ and bordering chlorenchyma could also explain the reduced frequency of protein unloading from the phloem.

Reports indicate that certain viruses such as CMV, CPMV, and TAV accumulate in major and minor leaf veins but are limited from escaping minor veins (Blackman et al. 1998; Silva et al. 2002; Thompson and Garcia-Arenal 1998). These may represent evidence of cellular mechanisms to limit foreign proteins or viruses that threaten developmental or metabolic cues expressed in surrounding tissues which could impact differentiation. This raises the question of why phloem unloading of the transgenically expressed GFP:TGBp1 and GFP:CP proteins in virus-infected plants is not limited in minor veins in this study. One explanation is that TGBp1 and CP are known to form a ribonucleoprotein complex with PVX RNA and this complex can be transported through the phloem and unload in sink tissues. If proteolysis is responsible for restricting GFP:GFP, GFP:TGBp1, and GFP:CP in the phloem, it is possible that a ribonucleoprotein complex containing GFP:TGBp1 or GFP:CP is protected from degradation. GFP:GFP failed to exit major and minor veins in PVX-GUS-infected leaves, indicating that there is a specific interaction between PVX and its cognate proteins to enable phloem unloading which could be explained by a proteasome-resistant ribonucleoprotein complex.

Linking proteolysis to virus and protein exit from CC-SE complexes is not entirely a new idea (Fisher et al. 1992; Jin et al. 2006). The role of proteolytic enzymes in regulating phloemlimited proteins was first determined in experiments showing Pprotein synthesis and turnover in the CC-SE complex. These data suggest that minor veins are not symplastically isolated from surrounding tissues but that cross-talk between neighboring cells is selective and is partly controlled by proteolysis. Furthermore, recent studies have shown that the RNA-silencing mechanism is active in the phloem (Smith et al. 2007; Voinnet and Baulcombe 1997). Viral proteins which suppress RNA silencing are often considered to be positive effectors for phloem transport, although we do not understand how these effectors function to enable phloem transport and unloading (Cronin et al. 1995; Voinnet et al. 2000). Thus, considering the studies linking protein and RNA degradation to phloem transport, it is reasonable to consider these to be factors in addition to physical barriers controlling selectivity in various veins and tissues.

These results differ from a prior report showing that PVXGFP unloading from minor veins is restricted. However, we do not know if PVX-GFP is prevented from accumulating in minor veins or exiting minor veins (Roberts et al. 1997). It is possible that PVX is restricted in protophloem or immature SE of developing minor veins. If virus entry into minor veins is restricted in nontransgenic $N$. benthamiana, then virus unloading from these same veins would not be detected. Such a restriction could be developmental. Limited access to the minor veins could create a bottleneck causing significantly more virus to accumulate in and unload from class III veins. Related studies exploring unloading of GFP from the phloem relied on the AtSUC2 promoter, and protein unloading from minor veins was also limited. However, AtSUC2 promoter activity is dependent upon vein maturation and is light responsive (Imlau et al. 1999; Stadler et al. 2005). One important difference between the current investigation and prior reports of PVX-GFP or GFP fused to the AtSUC2 promoter is the use of transgenic plants already expressing viral movement proteins in developing $\mathrm{CC}$. The CoYMV promoter is active in $\mathrm{CC}$ neighboring immature $\mathrm{SE}$, indicating that promoter activity is less affected by vein maturation than the AtSUC2 promoter or perhaps an invading PVX-GFP virus (Matsuda et al. 2002; Medberry et al. 1992). Thus, the best explanation is that the transgenic system delivers GFP:TGBp1 and GFP:CP proteins to minor vein phloem ahead of infection and these proteins may function in trans to enable PVX-GUS to spread further than seen during a normal virus infection. Because the transgenic GFP:TGBp1 and GFP:CP proteins are already expressed in developing phloem, we determined that there are occasions when proteins can unload from the phloem of minor veins, indicating that the plasmodesmata connections are not occluded.

A related investigation using transgenic plants expressing CMV 3a fused to GFP and the CoYMV promoter showed similar movement of 3a:GFP into xylem parenchyma in stems and leaves. Movement of 3a:GFP into nonvascular cells surrounding major and minor leaf veins was described as infrequent in young and mature leaves (Itaya et al. 2002). Similar to the observations for GFP:TGBp1 and GFP:CP movement in virus-infected leaves, movement of the 3a:GFP fusion outside the vasculature 
was usually one to two cells, under conditions when GFP:GFP fusions were restricted to the phloem. Thus, the limited ability of GFP:TGBp1 and GFP:CP to move across a barrier that also restricts diffusional movement of GFP:GFP suggests there may be functional similarities between these PVX proteins and CMV 3a (Itaya et al. 2002; Matsuda et al. 2002).

Recent investigations used the AtSUC2 promoter to trigger silencing of the phytoene desaturase, causing vein-centric photobleaching (Smith et al. 2007). Further evidence that an RNA-based antiviral mechanism operates in the phloem was shown in studies of the polerovirus P0 silencing suppressor. The polerovirus P0 directs ubiquitylation and proteasome degradation of AGOs but likely does not impact production of viral siRNAs (Baumberger et al. 2007; Bortolamiol et al. 2007). Because poleroviruses are normally phloem restricted, these studies implicate both the $26 \mathrm{~S}$ proteasome and RNAsilencing machinery as factors affecting phloem restriction. Importantly, these recent reports indicate that the $26 \mathrm{~S}$ proteasome is a factor modulating virus accumulation in the phloem by acting on a nonviral target. Immunoblot analysis shows that GFP:GFP, GFP:TGBp1, and GFP:CP accumulation are marginally impacted by the proteasome inhibitors, although phloem unloading seems to be unaffected; therefore, protein exit from the phloem is not driven by the concentrations of proteins in the CC-SE complex, but it is possible that the proteasome targets the machinery that regulates protein exit from the phloem rather than acting on the GFP fusions themselves. This explanation best supports the general effect of the inhibitors seen on all fusion proteins, including GFP:GFP. It is not likely that the proteasome inhibitors compromise phloem restriction of the CoYMV promoter because this would cause increased accumulation of all fusion proteins outside the phloem, which would be evidenced by higher protein levels in immunoblot analysis. Thus, the barrier to phloem exit provided by the chlorenchyma is not driven by protein concentrations in the phloem but by a selective mechanism that may be partly regulated by the $26 \mathrm{~S}$ proteasome.

In summary, there are many examples of viruses of vertebrates or invertebrates that are targets of the host proteasome machinery or are able to subvert or inhibit the proteasome machinery. The $26 \mathrm{~S}$ proteasome impacts systemic transport of TMV and TuMV (Jin et al. 2006), whereas the Potyvirus HCPro and the HIV-1 tat each target the 20S proteasome, inhibiting its ribonuclease activity (Apcher et al. 2003; Ballut et al. 2005; Jin et al. 2007), and HIV-1 tat recruits components of the $19 \mathrm{~S}$ proteasome to aid in viral RNA transcription (Lassot et al. 2007). On the other hand, hepatitis $B$ virus $X$ protein is degraded by the $26 \mathrm{~S}$ proteasome but also functions as an inhibitor of the proteasome complex (Hu et al. 1999). Thus, the final data presented in this article raise new possibilities to explore the unique relationship that PVX proteins have with the proteasome complex and the potential roles of proteasome complex in antiviral defense, virus susceptibility, or phloem translocation.

\section{MATERIALS AND METHODS}

\section{Bacterial strains and plasmids.}

The pCOI binary plasmid contains the CoYMV promoter, BamHI and SmaI restriction sites, and a pnos terminator (Fig. 1A). The pCOI and pCOI-GFP:GFP plasmids were obtained from B. Ding (Ohio State University) (Itaya et al. 2002). The pRTL2-GFP, -GFP:TGBp1, and -GFP:CP plasmids (Krishnamurthy et al. 2002, 2003) were digested with BamHI and EcoRI restriction enzymes and made blunt using T4 DNA polymerase (Promega Corp., Madison, WI, U.S.A.). The pCOI plasmid was digested with $S m a$ I and then treated with Calf intestinal alkaline phosphatase (Promega Corp.). Linearized vector and digested fragments were gel purified, ligated, and then used to transform Escherichia coli JM109 (Sambrook et al. 1989).

Each pCOI construct was introduced into Agrobacterium tumefaciens LBA4404 by electroporation in 2-mm cuvettes using the Gene Pulser (Bio-Rad Laboratories, Hercules, CA, U.S.A.). Voltage, resistance, and capacitance were adjusted to $2.5 \mathrm{kV}$, $200 \Omega$, and $25 \mu \mathrm{F}$, respectively. Following electroporation, Agrobacterium spp. were grown on YEP medium (yeast extract, $10 \mathrm{~g}$ liter ${ }^{-1}$; peptone, $10 \mathrm{~g} \mathrm{liter}^{-1}$; sodium chloride, $5 \mathrm{~g} \mathrm{liter}^{-1}$; agar, 15 $\left.\mathrm{g} \mathrm{liter}^{-1} ; \mathrm{pH} 7.0\right)$ containing streptomycin $\left(50 \mu \mathrm{g} \mathrm{ml}^{-1}\right)$ and kanamycin $\left(100 \mu \mathrm{g} \mathrm{ml}^{-1}\right)$. Colony PCR was used to verify that the Agrobacterium sp. contained the desired plasmids.

\section{Plant growth and transformation.}

$N$. benthamiana leaves were transformed with Agrobacterium spp. containing each of the six constructs as described previously (Verchot and Carrington 1995; Verchot et al. 1998). $N$. benthamiana leaves from 2-week-old greenhouse-grown plants were collected, surface sterilized with $10 \%$ Chlorox bleach for $10 \mathrm{~min}$, and washed thrice with sterile double-distilled (dd) $\mathrm{H}_{2} \mathrm{O}$. Agrobacterium and leaf segments were maintained on co-cultivation medium (Murashige and Skoog [MS] salts at $4.3 \mathrm{~g} \mathrm{liter}^{-1}$ [Sigma-Aldrich, St. Louis], sucrose at $30 \mathrm{~g}$ liter $^{-1}$, B5 vitamin at $1 \mathrm{~g} \mathrm{liter}^{-1}$, Phytoagar at $8 \mathrm{~g} \mathrm{liter}^{-1}$, and bacterial alkaline phosphatase [BAP] at $0.5 \mathrm{mg} \mathrm{liter}^{-1}$ ) for 3 days in the dark. Leaf segments were washed thrice with MS liquid medium and transferred to plates containing $N$. benthamiana shooting medium (MS salts at $4.3 \mathrm{~g} \mathrm{liter}^{-1}$, sucrose at 30 $\mathrm{g} \mathrm{liter}^{-1}$, B5 vitamin at $1 \mathrm{~g} \mathrm{liter}^{-1}$, Phytoagar at $8 \mathrm{~g} \mathrm{liter}^{-1}$, naphthalene acetic acid at $0.18 \mathrm{mg} \operatorname{liter}^{-1}$, BAP at $1.8 \mathrm{mg} \mathrm{liter}^{-1}$, carbenicillin at $250 \mathrm{mg} \mathrm{liter}^{-1}$, and kanamycin at $100 \mathrm{mg}$ liter $\left.{ }^{1}\right)$. After 2 weeks, the cultures were transferred to fresh $N$. benthamiana shooting medium. After approximately 4 weeks, shoots were transferred to $N$. benthamiana rooting medium (MS salts at $4.3 \mathrm{~g} \mathrm{liter}^{-1}$, sucrose at $5 \mathrm{~g} \mathrm{liter}^{-1}$, Phytoagar at $6 \mathrm{~g}$ liter ${ }^{-1}$, carbenicillin at $250 \mathrm{mg} \mathrm{liter}^{-1}$, and kanamycin at 100 mg liter ${ }^{-1}$ ). Transgenic $N$. benthamiana plantlets were transferred from rooting medium to magenta boxes containing sterile soil and then transferred to pots in the greenhouse. Some $N$. tabacum transgenics were also prepared and used in parallel experiments. The grafting experiments reported in Table 2 are results from experiments using transgenic $N$. tabacum.

\section{PCR analysis of transgenic plants.}

PCR was used to detect transgenes using leaf samples from the T0 and T1 lines listed in Table 1. PCR was carried out using a forward primer that overlapped with the $5^{\prime}$ end of the GFP coding sequence (GCG CCG CCC GGG ATG GTG AGC AAG GGC GAG GAG CTG). Reverse primers overlapped the $3^{\prime}$ ends of the PVX TGBp1 (CTA TGG CCC TGC GCG GAC ATA TGT CAA TCC CTT TG), PVX CP (CTC GAG TGA CAG CTG CAT CTA GGC TGG CAA AG), or GFP (GCG CCG GGT ACC TTA CTT GTA CAG CTC GTC CAT GCC) coding sequences.

To verify the presence of the CoYMV promoter, we employed a forward primer overlapping the $5^{\prime}$ end (CGG TAT GCC GGT TCC CAA GCT TTA TT) and a reverse primer overlapping the $3^{\prime}$ end (GCG CCG CTC GAG CTT GTT GTG TTG GTT TTC TAA GCT) of the CoYMV promoter. PCR reactions were carried out at $95^{\circ} \mathrm{C}$ for $2 \mathrm{~min}, 95^{\circ} \mathrm{C}$ for $45 \mathrm{~s}$, $60^{\circ} \mathrm{C}$ for $30 \mathrm{~s}$, and $72^{\circ} \mathrm{C}$ for either $1 \mathrm{~min}$ or $1.5 \mathrm{~min}$ (depending on the template) for 35 cycles.

\section{In vitro transcription, plant inoculations, and analysis of virus infection.}

The mMessage mMachine T7 kit (Ambion Inc., Austin, TX, U.S.A.) was used to prepare infectious PVX-GUS transcripts. 
SpeI linearized plasmid $(1 \mu \mathrm{g})$ was added to each transcription reaction. Transcription reactions were directly used to inoculate plants in the greenhouse (Ju et al. 2005). For some experiments, PVX-GUS-infected $N$. benthamiana leaves were excised and ground in a mortar and pestle with 2 volumes (wt/vol) of $0.1 \mathrm{M}$ phosphate buffer, $\mathrm{pH} 8.0\left(94 \mathrm{ml}\right.$ of $1 \mathrm{M} \mathrm{K}_{2} \mathrm{HPO}_{4}, 6 \mathrm{ml}$ of $1 \mathrm{M} \mathrm{KH}_{2} \mathrm{PO}_{4}$, plus $900 \mathrm{ml}$ of $\mathrm{ddH}_{2} \mathrm{O}$ ) plus $0.2 \% \beta$-mercaptoethanol ( $\mathrm{vol} / \mathrm{vol})$ and $10 \%$ ethanol $(\mathrm{vol} / \mathrm{vol})$ and used for inoculation.

Virus-inoculated and systemically infected leaves were excised from transgenic and nontransgenic $N$. benthamiana and $N$. tabacum plants approximately 2 weeks postinoculation. Leaf samples were collected from inoculated plants and vacuum infiltrated with a solution containing X-Gluc at $0.5 \mathrm{~g} \mathrm{liter}^{-1}$ (dissolved in 10 volumes [wt/vol] of dimethylformamide); 0.1 $\mathrm{M}$ sodium phosphate buffer, $\mathrm{pH} 7.0$ (57.7 ml of $1 \mathrm{M} \mathrm{Na}_{2} \mathrm{HPO}_{4}$, $42.3 \mathrm{ml}$ of $1 \mathrm{M} \mathrm{NAH}_{2} \mathrm{PO}_{4}$, plus $900 \mathrm{ml}$ of $\mathrm{ddH}_{2} \mathrm{O}$ ); EDTA 0.19 g liter ${ }^{-1} ; \mathrm{K}_{4} \mathrm{Fe}(\mathrm{CN})_{6}-3 \mathrm{H}_{2} \mathrm{O}$ at $0.232 \mathrm{~g} \mathrm{liter}^{-1} ; \mathrm{K}_{3} \mathrm{Fe}(\mathrm{CN})_{6}$ at $0.164 \mathrm{~g} \mathrm{liter}^{-1}$; and $1 \%$ Triton X-100 (Jefferson et al. 1987). Leaves were incubated overnight at $37^{\circ} \mathrm{C}$.

The PathoScreen kit (Agdia Inc., Elkhart, IN, U.S.A.) is a DAS-ELISA and was used to detect PVX in upper noninoculated leaves. Specifically, $0.1 \mathrm{~g}$ of leaf and $5 \mathrm{ml}$ of Agdia extraction buffer were placed in an extraction bag and samples were homogenized with a HOMEX 6 homogenizer (Bioreba Ag, CH-4153 Reinach BL1). DAS-ELISA was carried out according to PathoScreen kit instructions.

\section{Grafting and 5(6)-CF dye loading.}

Nontransgenic scions were grafted onto transgenic rootstocks. Scions carrying two leaves between 0.5 and $1 \mathrm{~cm}$ in length were taken from the tips of nontransgenic plants and stuck at a slant into a cutting made vertically along the side of the rootstock; these were fixed together with tape. To avoid desiccation, grafted plants were kept under a white plastic bag for 3 to 5 days in the plastic chamber. At 10 to 15 days after grafting, the portion of the rootstock above the graft union was removed. Plants were analyzed 2 to 4 weeks after grafting. Stem segments were cut with a razor blade starting from $0.5 \mathrm{~cm}$ above the interface of the graft union and analyzed by epifluorescence microscopy. Sections were photographed and scored for the presence of fluorescence in the CC, SE, vascular parenchyma, pith, and mesophyll cells. For some nontransgenic scions grafted onto nontransgenic rootstocks, a solution of 5(6)-CF dye (Invitrogen Corp, Carlsbad, CA, U.S.A.) at $0.24 \mathrm{mg} \mathrm{ml}^{-1}$ was applied to the petiole of a leaf at the rootstock (Krishnamurthy et al. 2002; Roberts et al. 1997). Translocation of the 5(6)-CF dye across the graft union was verified $6 \mathrm{~h}$ after application using epifluorescence microscopy to detect dye unloading in the scion leaves.

\section{Proteasome inhibitor treatments, Bradford assays, and immunoblot analysis.}

$N$. benthamiana leaves were infiltrated with a cocktail of $20 \mathrm{~S}$ and $26 \mathrm{~S}$ proteasome inhibitors $(50 \mu \mathrm{M}$ Z-Leu-Leu-Norvalinal [MG115] and $50 \mu \mathrm{M}$ Z-Leu-Leu-al [MG132] dissolved in MS medium) (Sigma-Aldrich) using a 1-ml syringe (BD Biosciences, San Jose, CA, U.S.A.). Leaves were examined microscopically for fluorescence unloading from veins. For some experiments, leaf punches around veins III, IV, and V were taken. Total protein from infiltrated leaves was extracted in 1:10 (wt/vol) grinding buffer $(100 \mathrm{mM}$ Tris- $\mathrm{HCl}, \mathrm{pH} 7.50$; $10 \mathrm{mM} \mathrm{KCl} ; 5 \mathrm{mM} \mathrm{MgCl} 2 ; 400 \mathrm{mM}$ sucrose; $10 \%$ glycerol; and $10 \mathrm{mM} \beta$-mercaptoethanol). Extracts were centrifuged at $10,000 \times g$ for $10 \mathrm{~min}$.

Standard Bradford assay reagent (Sigma-Aldrich) was used to quantify total proteins in leaf extracts. Then, $10 \mu \mathrm{g}$ of pro- teins were combined with protein loading buffer ( $2 \%$ sodium dodecyl sulfate [SDS]; $0.1 \mathrm{M}$ dithiothreitol; $50 \mathrm{mM}$ Tris- $\mathrm{HCl}$, pH $6.8 ; 0.1 \%$ bromophenol blue; and $10 \%$ glycerol) and boiled for 5 min, after which $12.5 \%$ SDS polyacrylamide gel electrophoresis was carried out for $1 \mathrm{~h}$ at $200 \mathrm{~V}$ using the Biorad Mini-Protean 3 system (Biorad Laboratories). Proteins were transferred to polyvinylidene diflouride membranes (Amersham Biosciences Corp., Piscataway, NJ, U.S.A.) at $4{ }^{\circ} \mathrm{C}$ overnight using protein transfer buffer $(39 \mathrm{mM}$ glycine, $48 \mathrm{mM}$ Tris base, $0.037 \%$ SDS, and $20 \%$ methanol, $\mathrm{pH} 8.3$ ) and a BioRad Trans-Blot system (Bio-Rad Laboratories). Immunoblot analyses were conducted using the ECL-Plus Western blotting detection kit (Amersham Biosciences Corp.) and GFP antiserum diluted 1:3000 (Chemicon International, Temecula, CA, U.S.A.). Films were imaged using the Alpha Image imaging system and Alpha Ease FC software for densitometric analysis (Alpha Innotech, San Leandro, CA, U.S.A.).

\section{Microscopy.}

Leaves of T0 plants were examined using a Nikon E600 epifluorescence microscope equipped with a B2A filter (Nikon Instrument Inc, Tokyo) to examine GFP expression when the plants were first transferred to soil. The 5(6)-CF dye was also analyzed in grafted plants using the Nikon E600 microscope. Images were captured using the Optronics Magnafire camera (Intelligent Imaging Innovations Inc., Denver) attached to the microscope. The Magnafire cooled CCD camera and software are integrated using FireWire technology, which provides live onscreen viewing of fluorescent material and can be used for focusing and framing prior to image capturing. The Magnafire dichroic color filters are 12 times more sensitive than cameras using liquid crystal filters. We routinely used the live imaging mode to view samples under the microscope and adjust zoom, contrast, brightness, and so on to differentiate artifacts or autofluorescence from GFP expression as well as determining whether GFP fluorescence is in single or multiple neighboring cells. The sensitivity of the camera allows us to identify low levels of fluorescence in neighboring cells. A Leica TCS SP2 system attached to a Leica DMRE microscope was used for confocal imaging.

\section{Statistics.}

All analyses were conducted with the use of PC SAS (version 9.1; SAS Institute, Cary, NC, U.S.A.). Contingency tables using $\chi^{2}$ tests to judge significance (PROC FREQ) were created to compare percentages of fluorescent signals associated with differences in transgenes. These tables were performed for each serum and each field type. If the test for all percentages exhibited significance, pair-wise tests were employed to further separate the percentages. Results are reported in Table 2. A significance level of 0.05 was used for all comparisons.

\section{ACKNOWLEDGMENTS}

We thank B. Ding (Ohio State University) for providing pCOIGFP:GFP plasmids and C.-M. Ye for preparation of PVX TGBp1 antisera and assistance with densitometry. This work was supported by the $\mathrm{Na}$ tional Science Foundation (NSF) Integrative Plant Biology Program Award (IBM-9982552), the NSF Multi-user Instrumentation Award (DBI0400580), and the Oklahoma Agriculture Experiment Station (project H2371).

\section{LITERATURE CITED}

Angell, S. M., and Baulcombe, D. C. 1995. Cell-to-cell movement of potato virus $\mathrm{X}$ revealed by micro-injection of a viral vector tagged with the beta-glucuronidase gene. Plant J. 7:135-140.

Aoki, K., Kragler, F., Xoconostle-Cazares, B., and Lucas, W. J. 2002. A 
subclass of plant heat shock cognate 70 chaperones carries a motif that facilitates trafficking through plasmodesmata. Proc. Natl. Acad. Sci. U.S.A. 99:16342-16347.

Apcher, G. S., Heink, S., Zantopf, D., Kloetzel, P. M., Schmid, H. P. Mayer, R. J., and Kruger, E. 2003. Human immunodeficiency virus-1 Tat protein interacts with distinct proteasomal alpha nd beta subunits. FEBS (Fed. Eur. Biochem. Soc.) Lett. 553:200-204.

Arce-Johnson, P., Reimann-Philipp, U., Padgett, H. S., Rivera-Bustamante, R., and Beachy, R. N. 1997. Requirement of the movement protein for long distance spread of Tobacco mosaic virus in grafted plants. Mol. Plant-Microbe Interact. 10:691-699.

Avery, J. G. S. 1933. Structure and development of the tobacco leaf. Am. J. Bot. 20:565-592.

Balachandran, S., Xiang, Y., Schobert, C., Thompson, G. A., and Lucas, W. J. 1997. Phloem sap proteins from Cucurbita maxima and Ricinus communis have the capacity to traffic cell to cell through plasmodesmata. Proc. Natl. Acad. Sci. U.S.A. 94:14150-14155.

Ballut, L., Drucker, M., Pugniere, M., Cambon, F., Blanc, S., Roquet, F., Candresse, T., Schmid, H. P., Nicolas, P., Gall, O. L., and Badaoui, S. 2005. HcPro, a multifunctional protein encoded by a plant RNA virus. targets the 20S proteasome and affects its enzymic activities. J. Gen. Virol. 86:2595-2603.

Baumberger, N., Tsai, C. H., Lie, M., Havecker, E., and Baulcombe, D. C. 2007. The Polerovirus silencing suppressor P0 targets ARGONAUTE proteins for degradation. Curr. Biol. 17:1609-1614.

Blackman, L. M., Boevink, P., Cruz, S. S., Palukaitis, P., and Oparka, K. J. 1998. The movement protein of cucumber mosaic virus traffics into sieve elements in minor veins of Nicotiana clevelandii. Plant Cell 10:525-538

Bortolamiol, D., Pazhouhandeh, M., Marrocco, K., Genschik, P., and Ziegler-Graff, V. 2007. The Polerovirus F box protein P0 targets ARGONAUTE1 to suppress RNA silencing. Curr. Biol. 17:1615-1621.

Botha, C. E., and Van Bel, A. 1992. Quantification of symplastic continuity as visualised by plasmodesmograms: diagnostic value for phloemloading pathways. Planta 187:359-366.

Carrington, J. C., and Whitham, S. A. 1998. Viral invasion and host defense: strategies and counter-strategies. Curr. Opin. Plant Biol. 1:336341

Carrington, J. C., Kasschau, K. D., Mahajan, S. K., and Schaad, M. C. 1996. Cell-to-cell and long-distance transport of viruses in plants. Plant Cell 8:1669-1681

Cheng, N. H., Su, C. L., Carter, S. A., and Nelson, R. S. 2000. Vascular invasion routes and systemic accumulation patterns of Tobacco mosaic virus in Nicotiana benthamiana. Plant J. 23:349-362

Cronin, S., Verchot, J., Haldeman-Cahill, R., Schaad, M. C., and Carrington, J. C. 1995. Long-distance movement factor: a transport function of the potyvirus helper component proteinase. Plant Cell 7:549-559.

Dasgupta, R., Garcia, B. H., 2nd, and Goodman, R. M. 2001. Systemic spread of an RNA insect virus in plants expressing plant viral movement protein genes. Proc. Natl. Acad. Sci. U.S.A. 98:4910-4915.

Deom, C. M., He, X. Z., Beachy, R. N., and Weissinger, A. K. 1994. Influence of heterologous tobamovirus movement protein and chimericmovement protein genes on cell-to-cell and long-distance movement. Virology 205(1):198-209.

Ding, B., Itaya, A., and Qi, Y. 2003. Symplasmic protein and RNA traffic: Regulatory points and regulatory factors. Curr. Opin. Plant Biol. 6:596602

Ding, X., Carter, S. A., Deom, C. M., and Nelson, R. S. 1998. Tobamovirus and Potyvirus accumulation in minor veins of inoculated leaves from representatives of the Solanaceae and Fabaceae. Plant Physiol. 116:125-136.

Fisher, D. B., Wu, Y., and Ku, M. S. 1992. Turnover of soluble proteins in the wheat sieve tube. Plant Physiol. 100:1433-1441.

Fujita, Y., Fujita, M., Mise, K., Kobori, T., Osaki, T., and Furusawa, I. 2000. Bromovirus movement protein conditions for the host specificity of virus movement through the vascular system and affects pathogenicity in cowpea. Mol. Plant-Microbe Interact. 13:1195-1203.

Giesman-Cookmeyer, D., Silver, S., Vaewhongs, A. A., Lommel, S. A. and Deom, C. M. 1995. Tobamovirus and dianthovirus movement proteins are functionally homologous. Virology 213:38-45.

Golecki, B., Schulz, A., and Thompson, G. A. 1999. Translocation of structural $\mathrm{P}$ proteins in the phloem. Plant Cell 11:127-140.

Gomez, G., and Pallas, V. 2004. A long-distance translocatable phloem protein from cucumber forms a ribonucleoprotein complex in vivo with Hop stunt viroid RNA. J. Virol. 78:10104-10110.

Gomez, G., Torres, H., and Pallas, V. 2005. Identification of translocatable RNA-binding phloem proteins from melon, potential components of the long-distance RNA transport system. Plant J. 41:107-116.

Haritatos, E., Medville, R., and Turgeon, R. 2000. Minor vein structure and sugar transport in Arabidopsis thaliana. Planta 211:105-111.
Hibberd, J. M., and Quick, W. P. 2002. Characteristics of C4 photosynthesis in stems and petioles of C3 flowering plants. Nature 415:451-454.

Howard, A. R., Heppler, M. L., Ju, H.-J., Krishnamurthy, K., Payton, M. E. and Verchot-Lubicz, J. 2004. Potato virus $X$ TGBp1 induces plasmodesmata gating and moves between cells in several host species whereas CP moves only in $N$. benthamiana leaves. Virology 328:185-197.

Hu, Z., Zhang, Z., Doo, E., Coux, O., Goldberg, A. L. and Liang, T. J. 1999. Hepatitis B virus $X$ protein is both a substrate and a potential inhibitor of the proteasome complex. J. Virl. 73:7231-7240.

Imlau, A., Truernit, E., and Sauer, N. 1999. Cell-to-cell and long-distance trafficking of the green fluorescent protein in the phloem and symplastic unloading of the protein into sink tissues. Plant Cell 11:309-322.

Itaya, A., Ma, F., Qi, Y., Matsuda, Y., Zhu, Y., Liang, G., and Ding, B. 2002. Plasmodesma-mediated selective protein traffic between "symplasmically isolated" cells probed by a viral movement protein. Plant Cell 14:2071-2083.

Jefferson, R. A., Kavanagh, T. A., and Bevan, M. W. 1987. GUS fusions: beta-glucuronidase as a sensitive and versatile gene fusion marker in higher plants. EMBO (Eur. Mol. Biol. Organ.) J. 6:3901-3907.

Jin, H., Li, S., and Villegas, A., Jr. 2006. Down-regulation of the $26 \mathrm{~S}$ proteasome subunit RPN9 inhibits viral systemic transport and alters plant vascular development. Plant Physiol. 142:651-661.

Jin, Y., Ma, D., Dong, J., Jin, J., Li, D., Deng, C., and Wang, T. 2007. HCPro protein of Potato virus Y can interact with three Arabidopsis $20 \mathrm{~S}$ proteasome subunits in planta. J. Virol. 81:12881-12888.

Ju, H. J., Samuels, T. D., Wang, Y. S., Blancaflor, E., Payton, M., Mitra, R., Krishnamurthy, K., Nelson, R. S., and Verchot-Lubicz, J. 2005. The Potato virus $X$ TGBp2 movement protein associates with endoplasmic reticulum-derived vesicles during virus infection. Plant Physiol. 138:1877-1895

Jin, H., Li, S., and Villegas, A., Jr. 2006. Down-regulation of the 26S proteasome subunit RPN9 inhibits viral systemic transport and alters plant vascular development. Plant Physiol. 142:651-661.

Klotz, K. L., Liu, T. T., Liu, L., and Lagrimini, L. M. 1998. Expression of the tobacco anionic peroxidase gene is tissue-specific and developmentally regulated. Plant Mol. Biol. 36:509-520.

Krishnamurthy, K., Mitra, R., Payton, M. E., and Verchot-Lubicz, J. 2002 Cell-to-cell movement of the PVX $12 \mathrm{~K}, 8 \mathrm{~K}$, or coat proteins may depend on the host, leaf developmental stage, and the PVX $25 \mathrm{~K}$ protein. Virology 300:269-281.

Krishnamurthy, K., Heppler, M., Mitra, R., Blancaflor, E., Payton, M., Nelson, R. S., and Verchot-Lubicz, J. 2003. The Potato virus X TGBp3 protein associates with the ER network for virus cell-to-cell movement. Virology 309(1):135-151.

Lassot, I., Latreille, D., Rousset, E., Sourisseau, M., Linares, L. K. Chable-Bessia, C., Coux, O., Benkirane, M., and Kiernan, R. E. 2007. The proteasome regulates HIV-1 transcription by both proteolytic and nonproteolytic mechanisms. Mol. Cell 25:369-383.

Lopez, L., Camas, A., Shivaji, R., Ankala, A., Williams, P., and Luthe, D. 2007. Mir1-CP, a novel defense cysteine protease accumulates in maize vascular tissues in response to herbivory. Planta 226:517-527.

Lough, T. J., Shash, K., Xoconostle-Cázares, B., Hofstra, K. R., Beck, D. L., Balmori, E., Forster, R. L. S., and Lucas, W. J. 1998. Molecular dissection of the mechanism by which potexvirus triple gene block proteins mediate cell-to-cell transport of infectious RNA. Mol. Plant-Microbe Interact. 11:801-814.

Lough, T. J., Netzler, N. E., Emerson, S. J., Sutherland, P., Carr, F., Beck, D. L., Lucas, W. J., and Forster, R. L. 2000. Cell-to-cell movement of potexviruses: evidence for a ribonucleoprotein complex involving the coat protein and first triple gene block protein. Mol. Plant-Microbe Interact. 13:962-974

Lough, T. J., Emerson, S. J., Lucas, W. J., and Forster, R. L. 2001. Transcomplementation of long-distance movement of White clover mosaic virus triple gene block (TGB) mutants: phloem-associated movement of TGBp1. Virology 288:18-28.

Lucas, W. J., and Wolf, S. 1999. Connections between virus movement, macromolecular signaling and assimilate allocation. Curr. Opin. Plant Biol. 2:192-197.

Matsuda, Y., Liang, G., Zhu, Y., Ma, F., Nelson, R. S., and Ding, B. 2002. The Commelina yellow mottle virus promoter drives companion-cellspecific gene expression in multiple organs of transgenic tobacco. Protoplasma 220:51-58.

Medberry, S. L., and Olszewski, N. E. 1993. Identification of cis elements involved in Commelina yellow mottle virus promoter activity. Plant $\mathrm{J}$. 3:619-626.

Medberry, S. L., Lockhart, B. E., and Olszewski, N. E. 1992. The Commelina yellow mottle virus promoter is a strong promoter in vascular and reproductive tissues. Plant Cell 4:185-192.

Metcalfe, C., and Chalk, L. 1979. Anatomy of the Dicotyledons, 1st ed. volume 1. Clarendon Press, Oxford. 
Meyer, S., Lauterbach, C., Niedermeier, M., Barth, I., Sjolund, R. D., and Sauer, N. 2004. Wounding enhances expression of AtSUC3, a sucrose transporter from Arabidopsis sieve elements and sink tissues. Plant Physiol. 134:684-693.

Nelson, R. S., and Van Bel, A. 1998. The mystery of virus trafficking into, through, and out of vascular tissue. Prog. Bot. 59:476-533.

Oparka, K. J., and Turgeon, R. 1999. Sieve elements and companion cellstraffic control centers of the phloem. Plant Cell 11:739-750.

Paramonova, N., Krasavina, M., and Sokolova, S. 2002. Ultrastructure of chloroplasts in phloem companion cells and mesophyll cells as related to the stimulation of sink activity by cytokinins. Russ. J. Plant Physiol. 49:187-195

Qi, Y., Pelissier, T., Itaya, A., Hunt, E., Wassenegger, M., and Ding, B. 2004. Direct role of a viroid RNA motif in mediating directional RNA trafficking across a specific cellular boundary. Plant Cell 16:1741-1752.

Reichel, C., and Beachy, R. N. 2000. Degradation of Tobacco mosaic virus movement protein by the $26 \mathrm{~S}$ proteasome. J. Virol. 74:3330-3337.

Roberts, A. G., Cruz, S. S., Roberts, I. M., Prior, D., Turgeon, R., and Oparka, K. J. 1997. Phloem unloading in sink leaves of Nicotiana benthamiana: comparison of a fluorescent solute with a fluorescent virus. Plant Cell 9:1381-1396.

Roberts, I. M., Boevink, P., Roberts, A. G., Sauer, N., Reichel, C., and Oparka, K. J. 2001. Dynamic changes in the frequency and architecture of plasmodesmata during the sink-source transition in tobacco leaves. Protoplasma 218:31-44

Rodionova, N. P., Karpova, O. V., Kozlovsky, S. V., Zayakina, O. V., Arkhipenko, M. V., and Atabekov, J. G. 2003. Linear remodeling of helical virus by movement protein binding. J. Mol. Biol. 333:565-572.

Sambrook, J., Fritsch, E. F., and Maniatis, T. 1989. Molecular Cloning: A Laboratory Manual. 2nd ed. Cold Spring Harbor Press, Cold Spring Harbor, NY, U.S.A.

SantaCruz, S., Roberts, A. G., Prior, D. A., Chapman, S., and Oparka, K. J. 1998. Cell-to-cell and phloem-mediated transport of potato virus X. The role of virions. Plant Cell 10:495-510.

Savenkov, E. I., and Valkonen, J. P. 2001. Potyviral helper-component proteinase expressed in transgenic plants enhances titers of Potato leaf roll virus but does not alleviate its phloem limitation. Virology 283:285-293.

Schoenknecht, G., Brown, J. E., and Verchot-Lubicz, J. 2008. Plasmodesmata transport of GFP alone or fused to Potato virus $X$ TGBp1 is diffusion driven. Protoplasma 232:142-152.

Silva, M. S., Wellink, J., Goldbach, R. W., and van Lent, J. W. 2002. Phloem loading and unloading of Cowpea mosaic virus in Vigna unguiculata. J. Gen. Virol. 83:1493-1504.
Smith, L. M., Pontes, O., Searle, I., Yelina, N., Yousafzai, F. K., Herr, A. J., Pikaard, C. S., and Baulcombe, D. C. 2007. An SNF2 protein associated with nuclear RNA silencing and the spread of a silencing signal between cells in Arabidopsis. Plant Cell 19:1507-1521.

Stadler, R., Wright, K. M., Lauterbach, C., Amon, G., Gahrtz, M., Feuerstein, A., Oparka, K. J., and Sauer, N. 2005. Expression of GFPfusions in Arabidopsis companion cells reveals non-specific protein trafficking into sieve elements and identifies a novel post-phloem domain in roots. Plant J. 41:319-331.

Thompson, J. R., and Garcia-Arenal, F. 1998. The bundle sheath-phloem interface of Cucumis sativus is a boundary to systemic infection by Tomato aspermy virus. Mol. Plant-Microbe Interact. 11:109-114.

Trip, P., and Gorham, P. R. 1968. Translocation of sugar and tritiated water in squash plants. Plant Physiol. 43:1845-1849.

Van Bel, A. 1996. Interaction between sieve element and companion cell and the consequences for photoassimilate distribution: two structural hardware frames with associated physiological software packages in dicotyledons? J. Exp. Bot. 47:1129-1140.

Van Bel, A. J., Ehlers, K., and Knoblauch, M. 2002. Sieve elements caught in the act. Trends Plant Sci. 7:126-132.

Verchot, J., and Carrington, J. C. 1995. Evidence that the potyvirus P1 proteinase functions in trans as an accessory factor for genome amplification. J. Virol. 69:3668-3674.

Verchot, J., Angell, S. M., and Baulcombe, D. C. 1998. In vivo translation of the triple gene block of potato virus $\mathrm{X}$ requires two subgenomic mRNAs. J. Virol. 72:8316-8320.

Voinnet, O., and Baulcombe, D. C. 1997. Systemic signalling in gene silencing. Nature 389:553.

Voinnet, O., Lederer, C., and Baulcombe, D. C. 2000. A viral movement protein prevents spread of the gene silencing signal in Nicotiana benthamiana. Cell 103:157-167.

Wang, H. L., Wang, Y., Giesman-Cookmeyer, D., Lommel, S. A., and Lucas, W. J. 1998. Mutations in viral movement protein alter systemic infection and identify an intercellular barrier to entry into the phloem long-distance transport system. Virology 245:75-89.

Wintermantel, W. M., Banerjee, N., Oliver, J. C., Paolillo, D. J., and Zaitlin, M. 1997. Cucumber mosaic virus is restricted from entering minor veins in transgenic tobacco exhibiting replicase-mediated resistance. Virology 231:248-257.

Wright, K. M., Roberts, A. G., Martens, H. J., Sauer, N., and Oparka, K. J. 2003. Structural and functional vein maturation in developing tobacco leaves in relation to AtSUC2 promoter activity. Plant Physiol. 131:1555-1565. 